\title{
Boundary elements of the Tetrahymena telomerase RNA template and alignment domains
}

\author{
Chantal Autexier and Carol W. Greider ${ }^{1}$ \\ Cold Spring Harbor Laboratory, Cold Spring Harbor, New York 11724 USA
}

\begin{abstract}
Telomerase is a DNA polymerase fundamental to the replication and maintenance of telomere sequences at chromosome ends. The RNA component of telomerase is essential for the synthesis of telomere repeats. In vitro, the template domain (5'-CAACCCCAA-3') of the Tetrahymena telomerase RNA dictates the addition of Tetrahymena-specific telomere repeats d(TTGGGG) $)_{n}$, onto the 3' end of G-rich or telomeric substrates that are base-paired with the template and alignment regions of the RNA. Using a reconstituted in vitro system, we determined that altering the sequence of the alignment and template domains affects processivity of telomerase without abolishing telomerase activity. These results suggest that alternative template/alignment regions may be functional. In the ciliate telomerase RNAs, there is a conserved sequence $5^{\prime}$-(CU)GUCA-3', located two residues upstream of the template domain. The location and sequence of this conserved domain defined the $5^{\prime}$ boundary of the template region. These data provide insights into the regulation of telomere synthesis by telomerase.
\end{abstract}

[Key Words: Polymerase; ribonucleoprotein; Tetrahymena; telomerase; telomere]

Received May 4, 1995; revised version accepted August 2, 1995.

Telomerase is a DNA polymerase essential for the replication and maintenance of telomere sequences at the ends of chromosomes. Without telomeres, which serve as protective caps, chromosomes are prone to fusion with other chromosomes and to other DNA rearrangements (Muller 1938; McClintock 1941; for review, see Biessmann and Mason 1992). Generally, telomeres consist of short (5-8 bp) G-rich repeats, although exceptions to this exist, most notably in certain yeasts, where the repeat is 16-26 bp in length, and in Drosophila where no simple telomere repeats have been detected (Zakian 1989; Blackburn 1991; Greider 1991a; McEachern and Blackburn 1994; Mason and Biessmann 1995). Telomerase is a ribonucleoprotein (RNP) containing an essential RNA component that dictates the synthesis of telomeric repeats onto DNA substrates, both in vivo and in vitro (Greider and Blackburn 1989; Yu et al. 1990). Telomerase activity and RNA components were first identified in unicellular ciliated protozoa (Greider and Blackburn 1985, 1989; Zahler and Prescott 1988; Shippen-Lentz and Blackburn 1989, 1990; Lingner et al. 1994; Melek et al. 1994). Telomerase activity has also been identified in other organisms, including immortalized human and mouse cell lines, Xenopus laevis, and Sac-

${ }^{1}$ Corresponding author. charomyces cerevisiae (Morin 1989; Prowse et al. 1993; Mantell and Greider 1994; Cohn and Blackburn 1995; Lin and Zakian 1995). Recently the genes encoding the RNA components of telomerase from $S$. cerevisiae, Kluyveromyces lactis, human, and mouse have been cloned (Singer and Gottschling 1994; McEachern and Blackburn 1995; Blasco et al. 1995; Feng et al. 1995), and the protein components of telomerase from Tetrahymena thermophila have been identified and the corresponding cDNAs cloned (Collins et al. 1995).

In Tetrahymena cells expressing mutant telomerase RNAs, altered telomere sequences and lengths result in nuclear and cell division defects, and senescence (Yu et al. 1990). Disruption of the telomerase RNA gene in yeast results in shortened telomeres, a gradual increase in generation time, and a decrease in cell viability and cell death (Singer and Gottschling 1994; McEachern and Blackburn 1995). In primary human and mouse cell strains where telomerase activity is not detectable, telomere length decreases with increasing number of cell divisions in vitro and with age in vivo (Harley et al. 1990; Hastie et al. 1990; Allsopp et al. 1992; Prowse and Greider 1995). In unicellular ciliates telomere length is maintained through the action of telomerase (Yu et al. 1990). Telomere length is also maintained in vertebrate germline cells, immortalized cells, and tumors in which telomerase activity is detected, indicating a critical role for telomerase in telomere length regulation and poten- 
tially, in the growth of immortal cells (Counter et al. 1994; Kim et al. 1994; Mantell and Greider 1994; Prowse and Greider 1995).

The RNA component of telomerase is best characterized in the ciliates where it has been cloned from 20 species. The RNAs range from 148 to 191 nucleotides in length (Greider and Blackburn 1989; Shippen-Lentz and Blackburn 1990; Romero and Blackburn 1991; Lingner et al. 1994; McCormick-Graham and Romero 1995; Melek et al. 1994). Both in vitro and in vivo experiments have shown that the telomerase RNAs of different ciliate species contain short sequences (9-15 nucleotides) complementary to the species-specific telomeric repeats. These RNA sequences direct the synthesis of telomeric repeats by providing a template. The template region generally consists of sequences complementary to more than one telomeric repeat (for Tetrahymena, 5'-CAACCCCAA$\left.3^{\prime}\right)$. In Tetrahymena, in vitro reconstitution of telomerase activity from isolated protein and mutant RNA components showed that the extra residues in the template region $\left(5^{\prime}\right.$-CAACCCCAA-3') serve to align substrate and product DNA sequences (Autexier and Greider 1994).

To understand the role of telomerase in telomere length maintenance it is necessary to understand the mechanism of telomerase action. To dissect the function of the telomerase RNA, we analyzed the activity of Tetrahymena telomerase reconstituted in vitro with telomerase RNA mutants. Altering the sequence of the alignment and template domains affected processivity without abolishing telomerase activity. These results suggest that alternative template/alignment regions adjacent to the wild-type template/alignment domains may be used. The location and sequence of a previously identified conserved region 5'-(CU)GUCA-3' (Romero and Blackburn 1991; Lingner et al. 1994; McCormickGraham and Romero 1995) defined the $5^{\prime}$ boundary of the template. These experiments provide insight into the regulation of telomere repeat synthesis.

\section{Results}

Changes in the length of the template region of telomerase RNA are accommodated by telomerase

Addition of a $C$ residue to the telomerase RNA template region $\left(5^{\prime}\right.$-CAACCCCCAA- $\left.3^{\prime}\right)$ specifies the synthesis of $5^{\prime}$-GGGGGTT-3' repeats in vivo, indicating that the extra $\mathrm{C}$ residue serves as a template residue (Yu et al. 1990). To determine the effects of template length changes in vitro, we used a reconstitution system (Autexier and Greider 1994) to test a similar mutant $(5 \mathrm{C})$ and mutants with fewer $\mathrm{C}$ residues in the template $(3 \mathrm{C}$ and $2 \mathrm{C})$. The sequences of the template and alignment domains of these mutants are illustrated in Figure 1.

In vitro, Tetrahymena telomerase can elongate telomeric substrates processively generating a distinct 6-nucleotide banding pattern or periodicity /Greider and Blackburn 1985; Greider 1991b). The strongly labeled product within the repeat pattern represents a pause in elongation after the addition of the first $\mathrm{G}$ residue in the sequence GGGGTT (Greider 1991b). After this pause, which occurs at the extreme $5^{\prime}$ end of the template region, the enzyme translocates to initiate another round of telomeric repeat synthesis (Greider and Blackburn 1989). The sequence at the 3 ' end of telomeric substrates specifies the first nucleotide added in elongation reactions with telomerase. For example, a G residue will be added first to a telomeric primer ending in the sequence $\mathrm{d}$ (GGGGTT), whereas a $\mathrm{T}$ residue will be added to a primer ending in the sequence d(TTGGGG) (Greider and Blackburn 1987; Zahler and Prescott 1988; Morin 1989; Shippen-Lentz and Blackburn 1989|. Dideoxynucleotides (ddNTPs) can be used to determine the nucleotide sequence added onto telomeric primers by telomerase (Greider and Blackburn 1985; Greider 1991b; Autexier and Greider 1994).

Elongation assays were performed using telomerase reconstituted with the $2 \mathrm{C}, 3 \mathrm{C}$, wild-type, or $5 \mathrm{C}$ telomerase RNAs (Fig. 1). Elongation products in the presence of $\left[\alpha-{ }^{32} \mathrm{P}\right] \mathrm{dGTP}$ and either dTTP or ddTTP were analyzed, using three different oligonucleotide primers with permutations of the telomeric sequence d(GGGGTT) $)_{3}$. The potential alignment of each primer with the telomerase RNAs is shown in Figure 1.

The length of the template region affected the synthesis of short and long elongation products. With each primer, $\left[\alpha^{-32} \mathrm{P}\right] \mathrm{dGTP}$ and dTTP, the 3C and 5C mutant generated short and long elongation products, although fewer than wild type, whereas the $2 \mathrm{C}$ mutant synthesized predominantly short products, corresponding to the synthesis of one repeat (e.g., lanes $1,3,5,7)$. At a low efficiency, long products were generated by the $2 \mathrm{C}$ RNA, visible on longer exposures of this and other experiments (data not shown). With $\left[\alpha{ }^{32} \mathrm{P}\right] \mathrm{dGTP}$ and dTTP, the $2 \mathrm{C}$ mutant specified the addition of 4 residues onto the $3^{\prime}$ end of the primer d(GGGTTG) ${ }_{3}$ before stopping at the $5^{\prime}$ end of the template (lane 1). Three residues were added onto the $3^{\prime}$ ends of the primers d(GGTTGG) $)_{3}$ and d(GTTGGG) $_{3}$ (lanes 9,17 ), indicating that these primers align at the same position within the RNA. With the 3C RNA, 5,4 , and 3 residues were added onto the $3^{\prime}$ end of the primers d(GGGTTG) $)_{3}$ d(GGTTGG) $)_{3}$, and d(GTTGGG) $)_{3}$, respectively, before translocation at the $5^{\prime}$ end of the template. With the 5C RNA, 7, 6, and 5 residues were added onto the $3^{\prime}$ end of the primers $\mathrm{d}(\mathrm{GGGTTG})_{3}, \mathrm{~d}(\mathrm{G}$ GTTGG $_{3}$, and d(GTTGGG) $)_{3}$, respectively, before stopping at the 5 ' end of the template (lanes $7,15,23$ ). Not all primers tested were elongated with the same efficiency. Telomerase reconstituted with wild type RNA elongates all six Tetrahymena telomeric oligonucleotide permutations with similar efficiencies (Autexier and Greider 1994). The 5C mutant elongated only d(GGTTGG) 3 , d(GTTGGG) $)_{3}$, and less efficiently, d(GGGTTG $)_{3}$. The other permutations tested resulted in few, if any visible products at the primer concentrations tested /data not shown).

For the 2C, 3C, wild-type, and 5C RNAs, the incorporation of ddTTP into elongation products was dictated by the number of $\mathrm{C}$ residues in the template region. In the 

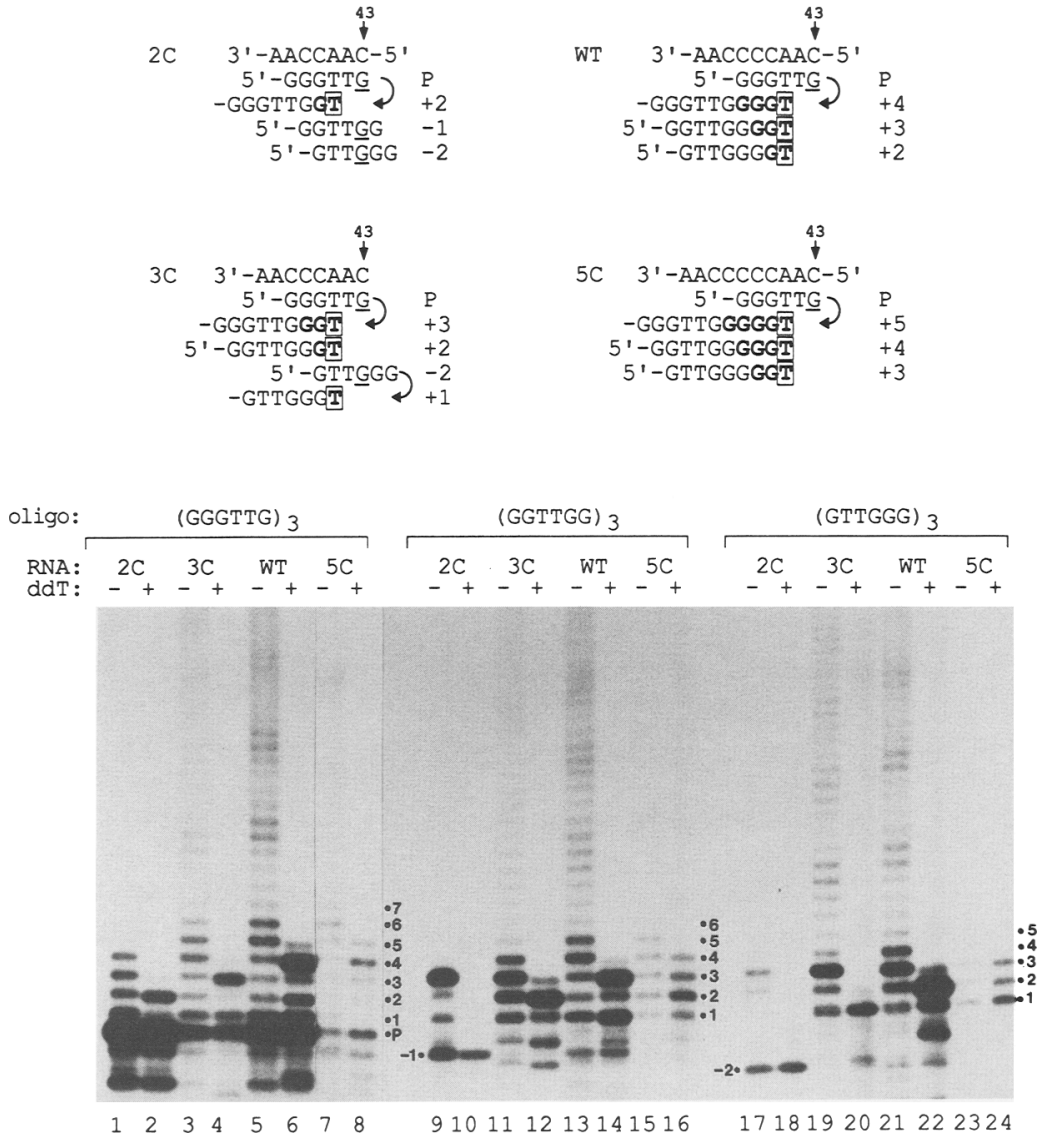

Figure 1. Reconstitution of telomerase activity using mutant telomerase RNAs of various template lengths. (Top) Schematic diagram of the mutant RNAs used in reconstitution aligned with the telomeric oligonucleotides used in the telomerase assays. Nucleotides in bold represent nucleotides added onto the 3 ' end of the primers before and including the addition of ddTTP (boxed T). The numbers to the right of the sequences $1+1$, $+2,+3,+4,+5)$ indicate the number of residues added onto the $3^{\prime}$ end of the primers before incorporation of ddTTP. P refers to primer size-labeled product (18 nucleotides), -1 refers to a 17 -nucleotide-labeled product, and -2 to a 16-nucleotide labeled product. Arrows on top of the RNA sequences indicate the extreme $5^{\prime}$ end of the template (residue 43 of the RNA) and the position of primer or product cleavage (cleaved $\mathrm{G}$ residue is underlined). The curved arrows indicate translocation of the product DNA. (Bottom) Elongation products of telomerase reconstituted with $2 \mathrm{C}$ (lanes 1,2,9,10,17,18), 3C (lanes 3,4,11,12,19,20), wild type (WT) (lanes 5,6,13,14,21,22), and 5C (lanes $7,8,15,16,23,24)$ and assayed in the presence of $\left[\alpha^{-32} \mathrm{P}\right] \mathrm{dGTP}$ and dTTP (lanes $1,3,5,7,9$, $11,13,15,17,19,21,23$ ) or ddTTP (lanes $2,4,6,8,10$, $12,14,16,18,20,22,24)$ and telomeric primers d(GGGTTG) $)_{3}$ (lanes 1-8), d(GGTTGG) ${ }_{3}$ (lanes 9-16), or d(GTTGGG) (lanes 17-24). The numbers on the right of the elongation products indicate the number of residues added to the $3^{\prime}$ end of the primers tested. The gel was exposed to film for 4 days (lanes 1-6; 9-24) or 6 days (lanes 7,8). schematic in Figure 1, the boxed $\mathrm{T}$ residues represent ddTTP and the numbers to the right of the primer sequences indicate the number of residues (in bold), including ddTTP, added onto the $3^{\prime}$ ends of the respective primers. In reactions with $\left[\alpha-{ }^{32} \mathrm{P}\right] \mathrm{dGTP}$, ddTTP, and $2 \mathrm{C}$ RNA, only 2 residues were added onto the primer d(GGGTTG) ${ }_{3}$ consistent with the addition of dGddT (lane 2). For the 3C RNA, chain termination occurred after the addition of 3 residues onto the same primer (lane 4). For wild-type RNA, chain termination occurred after the addition of 4 residues, as expected. For the $5 \mathrm{C}$ mutant, labeled products were present at position +4 as well as +5 (lane 8), possibly attributable to misalignment of the primer with the longer template. Products at +5 are expected if all the $C$ residues were serving as template nucleotides. In vivo, this mutant has reduced fidelity, generating $T_{2} G_{6-8}$ as well as $T_{2} G_{5}$ repeats $(Y u$ and Blackburn 1991), presumably the result of misalignment. During elongation of the $\mathrm{d}\left(\mathrm{GGTTGG}_{3}\right.$ primer, in the presence of ddTTP, stops occurred at positions +2 , +3 , and +4 for the $3 \mathrm{C}$, wild-type, and 5C RNAs, respectively (lanes 12, 14, 16), and during elongation of the primer d(GTTGGG) $)_{3}$, with ddTTP, stops occurred at positions $+1,+2$, and +3 for the 3C, wild-type, and $5 \mathrm{C}$ RNAs, respectively (lanes $20,22,24$ ), indicating the altered templates were used to specify the added bases.

Tetrahymena telomerase possesses a specific nucle- olytic activity that cleaves primers that align at or beyond the extreme $5^{\prime}$ end of the template (position 43) (Collins and Greider 1993). The 2C mutant generated labeled products at positions primer minus one $(-1)$ and primer minus two $(-2)$ for primers d(GGTTGG) $)_{3}$ and d(GTTGGG) ${ }_{3}$, respectively (lanes $\left.9,10,17,18\right)$. This could be attributable to alignment of these primers beyond the $5^{\prime}$ end of the RNA template and cleavage of 2 or 3 residues, before template-directed addition of $\left[\alpha-{ }^{32} \mathrm{P}\right] \mathrm{dGTP}$ at positions -1 or -2 , respectively (underlined in Fig. 1). The $3 \mathrm{C}$ mutant also generated a labeled product at position -2 with d(GTTGGG) ${ }_{3}$ (lanes 19, 20). A primer size-labeled product $(\mathrm{P})$ that results from nucleolytic activity of telomerase was also detected for all RNAs tested with primer d(GGGTTG) ${ }_{3}$ (lanes 1-8). Thus, altering the length of the template did not abolish the cleavage activity associated with telomerase.

\section{Altering the sequence of the template and alignment regions of telomerase RNA decreases processivity}

Previously we defined template (positions 43-48; 5'CAACCCCAA- $3^{\prime}$ ) and alignment (positions 49-51; 5'CAACCCCAA- ${ }^{\prime}$ ) domains in the telomerase RNA (Autexier and Greider 1994). To determine whether the sequence of the template and alignment regions of the telomerase RNA are essential to template function and 
to the recognition and elongation of substrates by telomerase, RNAs with circularly permuted sequences within the 9-nucleotide template and alignment regions of the telomerase RNA (called temperl-temper5) were tested in reconstitution assays. The sequence of residues 43-54 of these RNA mutants and wild-type telomerase RNA are shown in Figure 2. Using the telomeric sequence primer $\mathrm{d}(\mathrm{GGGGTT})_{3}$, elongation products in the presence of $\left[\alpha{ }^{32} \mathrm{P}\right] \mathrm{dGTP}$ and either dTTP or ddTTP were analyzed (Fig. 2). Most of the mutants generated few, if any, long products, although all have the correct 9 nucleotides to specify potentially wild-type d(GGGGTT) $\left.\right|_{n}$ repeats. Quantitation of the long and short products confirmed the lower ratio of long-to-short products in the mutants. The ratios of the fourteenth to the first repeat were temperl, 0.14; temper2, 0.011; temper3, 0.025; temper 4, 0.03; temper5, 0.05; and wild type, 0.25 . This decrease in processivity suggests that alternative alignment/template domains are being used. In the presence of $\left[\alpha{ }^{32} \mathrm{P}\right] \mathrm{dGTP}$ and dTTP, temper3 generated products with a five, not six, base repeat (cf. lane 5 with lane 11). Temper 2 generated products with a 2-nucleotide banding pattern, suggesting the primer might be aligning and translocating at more than one location (lane 3), as shown in Figure 2. Alternative primer alignments that potentially extend the template/alignment domain more than 9 nucleotides are also possible for temperl, temper4, and temper5 (underlined A residues in Fig. 2).
With all RNAs except temper3, ddTTP incorporation occurred 5 residues from the $3^{\prime}$ end of the primer $\mathrm{d}\left(\right.$ GGGGTT $_{3}$ indicating the synthesis of wild-type repeats (lanes 2,4,8,10,12). For temper3, termination occurred predominantly at position +4 from the 3 ' end of

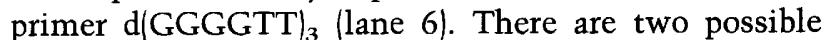
alignments of this primer with temper3 RNA, at positions 52 and 53 or at positions 47 and 48 . The 5 nucleotide periodicity of the elongation products, with dTTP, and the strongly labeled product at position +4 , with ddTTP, suggest that the alignment at positions 52 and 53 can occur, resulting in the synthesis of $d\left(G_{3} T_{2}\right)$ repeats rather than $d\left(G_{4} T_{2}\right)$ repeats. If this is the case, the template region must also be $3^{\prime}$ to the previously defined template region. In addition to a labeled product at position +4 , with ddTTP, some termination occurred at position +5 from the $3^{\prime}$ end of primer $\mathrm{d}\left(\right.$ GGGGTT) ${ }_{3}$ (lane 6) suggesting that these primers can also align at positions 47 and 48 of the temper3 RNA. However, alignment at this position would not result in the observed 5-bp periodicity of products seen with dTTP. To generate products in which ddTTP is incorporated at the indicated positions, temper 4 and temper 5 can align with the tested primers as indicated in Figure 2.

To address further whether alternative template/ alignment regions are functional, insertions were introduced at position 51 in the telomerase RNA. The sequence of these RNAs and all possible primer align-

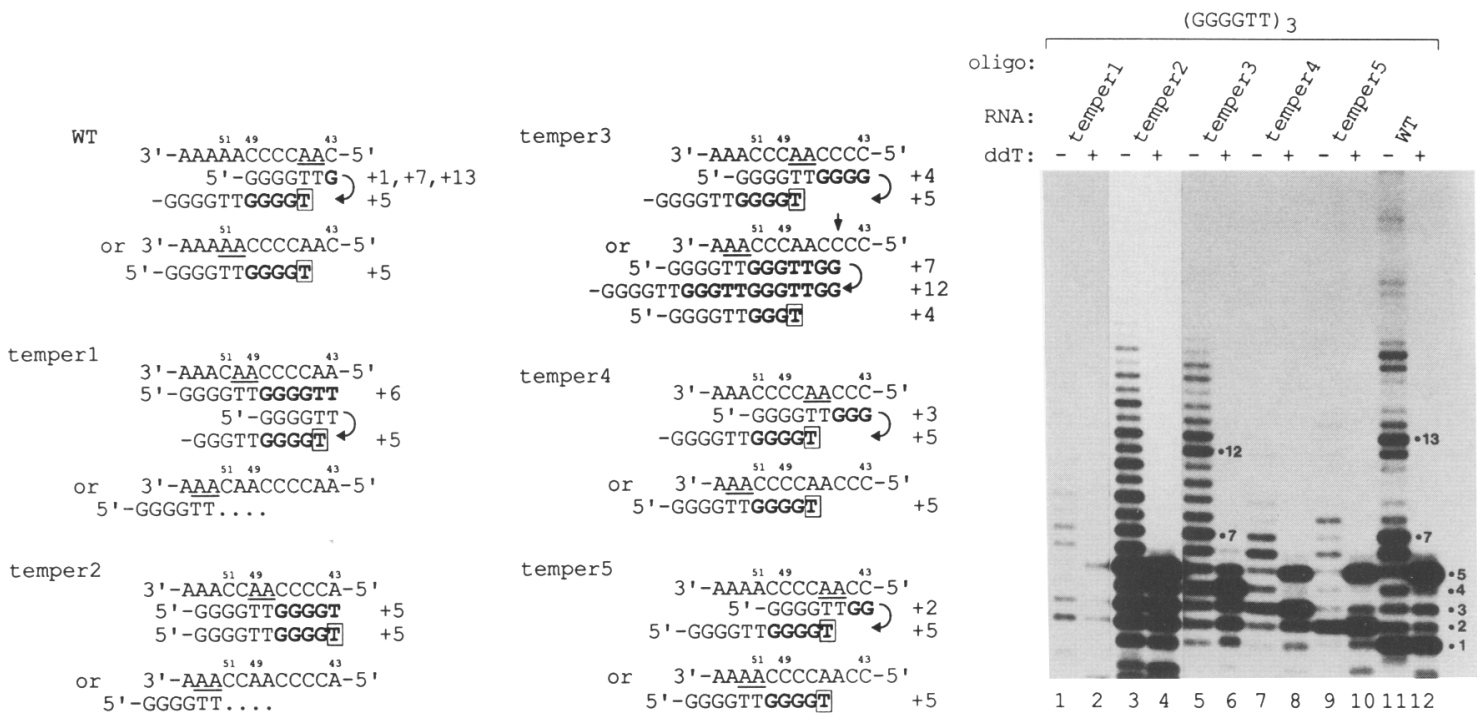

Figure 2. Reconstitution of telomerase activity with RNAs containing permutations of the template and alignment sequences. (Left) Schematic diagram of the sequence of the template permutations of the telomerase RNAs (from residues 43-54 of the RNAs) aligned with the telomeric oligonucleotide $\left(\right.$ GGGGTT) $_{3}$. The features in the diagram are similar to those in Fig. 1. Underlined A residues indicate the positions where the extreme 3' end of the primer d(GGGGTT) ${ }_{3}$ can align. (Right) The RNA mutants and oligonucleotide primer used are indicated in the figure: temperl (lanes 1,2), temper2 (lanes 3,4), temper3 (lanes 5,6), temper4 (lanes 7,8 ), temper5 (lanes $9,10$ ) or wild type (WT) (lanes 11,12$)$. Elongation reactions were carried out in the presence of $\left[\alpha-{ }^{32} \mathrm{P}\right] \mathrm{dGTP}$ and dTTP $(\mathrm{lanes} 1,3,5,7,9,11)$ or $\left[\alpha^{-32} \mathrm{P}\right] \mathrm{dGTP}$ and ddTTP (lanes $2,4,6,8,10,12$ ) as described. The numbers in the figure indicate the number of nucleotides added onto the input primers. In lanes 3 and 4 , products shorter than the primer are visible, indicating that temper 2 may have some cleavage activity. The gel was exposed to film for 2 days; however, lanes 3 and 4 are taken from a lighter exposure of the negative to clearly show the short products. 
ments are diagrammed in Figure 3 . The $51+2 \mathrm{U}$ RNA contains 2 extra $U$ residues at position 51 , whereas the $51+4 \mathrm{C}$ RNA contains 4 extra $\mathrm{C}$ residues at the same position, extending the template/alignment domain by 4-6 residues. Elongation products of telomerase reconstituted with $51+2 \mathrm{U}$ or $51+4 \mathrm{C}$ were analyzed and compared to wild-type elongation products (Fig. 3). Using primers d(GGGGTT) $)_{3}$ or d(GGGTTG $)_{3}$, and $\left[\alpha^{-32} \mathrm{P}\right] \mathrm{dGTP}$ and ddTTP, incorporation of ddTTP by telomerase reconstituted with wild-type, $51+2 \mathrm{U}$, or $51+4 \mathrm{C} \mathrm{RNA} \mathrm{oc-}$ curred at positions +5 and +4 from the $3^{\prime}$ end of each primer, respectively, consistent with the synthesis of $\mathrm{d}\left(\mathrm{G}_{4} \mathrm{~T}_{2}\right)$ repeats (lanes $\left.2,4,7,10,12,14\right)$. With the same primers and $\left[\alpha^{-32} \mathrm{P}\right] \mathrm{dGTP}$ and $\mathrm{dTTP}$, long elongation products were generated by telomerase reconstituted with $51+2$ U RNA, similarly to wild type /cf. lanes 1, 3, 5 , and 9). Both wild-type and $51+2 U$ RNA generated a primer size-labeled cleavage product in elongation reactions with d(GGGTTG) $)_{3}$, indicating alignment of the primer with the $5^{\prime}$ end of the template (lanes $\left.3,4,9,10\right)$. Elongation products generated by telomerase reconstituted by $51+2 \mathrm{U}$ were not dependent on dATP and ddATP was not incorporated into elongation products, suggesting that the 2 inserted $U$ residues in the 3 ' flanking region are not part of the template and that primer alignment is unlikely to be occurring $3^{\prime}$ to the insertion in this mutant (lanes 5, 6, 8).

Elongation of telomeric primers by telomerase reconstituted with $51+4 \mathrm{C}$ RNA generated few, if any, long products in telomerase reactions (lanes 11, 13). Moreover, no primer size-labeled product was generated by this mutant in elongation reactions with d(GGGTTG) ${ }_{3}$, suggesting that the alignment of this primer with $51+4 \mathrm{C}$ RNA is not occurring at the extreme $5^{\prime}$ end of the template (lanes 13,14$)$ and that extending the template/alignment domain from 9-15 residues resulted in nonprocessive synthesis of telomeric repeats.

\section{The location and sequence of the conserved region 5'-(CU) GUCA-3' define the 5' boundary of the template domain}

In telomerase RNAs from 20 ciliate species, there is a conserved sequence $5^{\prime}$-(CU)GUCA-3', located 2 residues upstream of the template domain (Romero and Blackburn 1991; Lingner et al. 1994; McCormick-Graham and Romero 1995). To test the function of this conserved sequence, first we assayed mutations that changed the spacing or sequence between this region and the template $(42 G, \Delta 42, \Delta 43$, and $42+\mathrm{U})$. All the mutant sequences, including the conserved region are illustrated in Figure 4A. The potential alignment of the primer tested, with the RNAs, the sequence and number of residues added (in bold) onto the primer are shown. Elongation products of telomerase reconstituted with these mutant RNAs were compared to elongation products of telomerase reconstituted with wild-type telomerase RNA and the $43 \mathrm{U}$ mutant RNA characterized previously (Autexier and Greider 1994)(Fig. 4B).

Telomerase reconstituted with wild-type telomerase

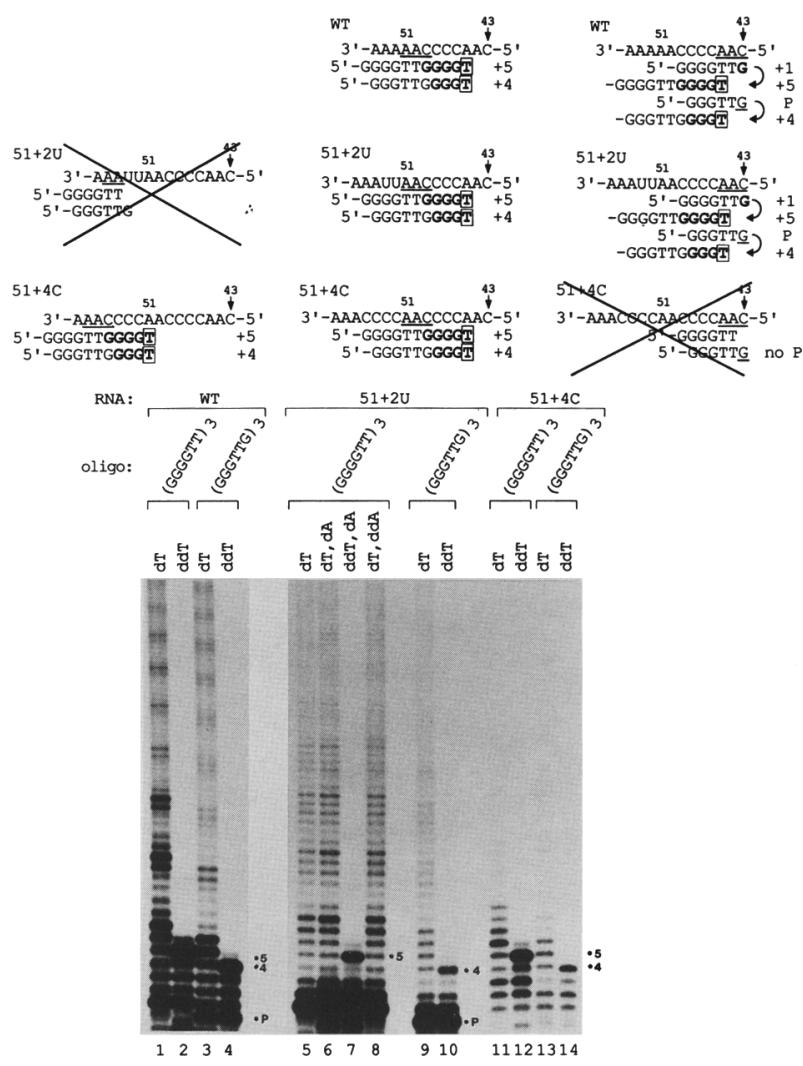

Figure 3. Telomerase can use alternative alignment regions. (Top) Schematic diagram illustrating the potential alignment of the telomeric primers d(GGGGTT) ${ }_{3}$ and $\mathrm{d}(\mathrm{GGGTTG})_{3}$ with wild type, $51+2 U$, and $51+4 C$ telomerase RNAs. Residues $43-$ 54 of the telomerase RNAs are shown. The features in the diagram are similar to those in Fig. 1. Our data (see text) suggest that certain alignments do not occur (crossed out in the schematicl. Underlined $3^{\prime}$-AAC-5' residues indicate the positions where the extreme $3^{\prime}$ end of the primers $d(G G G G T T)_{3}$ (A residues only) and d(GGGTTG) $)_{3}$ can align. (Bottom) Telomerase was reconstituted with wild type (WT) (lanes 1-4), 51+2U (lanes 5-10), or $51+4 \mathrm{C}$ (lanes 11-14) telomerase RNA. Elongation reactions were performed using primers d(GGGGTT) ${ }_{3}$ (lanes 1, 2, 5-8, 11, 12) or d(GGGTTG) (lanes 3, 4, 9, 10, 13, 14) in the presence of $\left[\alpha-{ }^{32} \mathrm{P}\right] \mathrm{dGTP}$ and the nucleotides indicated in the figure. The numbers refer to the number of nucleotides added onto the input primer (P). The gel was exposed to film for 2 days (lanes 1-4) and 4 days (lanes 5-14).

RNA generates long products with $\left[\alpha^{-32} \mathrm{P}\right] \mathrm{dGTP}$ and dTTP, whether dATP is added or not (Fig. 4B, lanes 1,2; Autexier and Greider 1994). ddATP is not incorporated into elongation products generated by wild-type RNA (lane 4; Autexier and Greider 1994), suggesting that the 2 $\mathrm{U}$ residues upstream of position 43 are not template residues. ddTTP incorporation occurred at the expected position $(+2)$ from the $3^{\prime}$ end of the primer d(GTTGGG) $)_{3}$ (lane 3). To test if changing the sequence of position 42 would result in incorporation of this residue into the template, the U residue was changed to all possible other nucleotides. No alteration in telomerase products was seen for these mutants (data not shown). For example, elongation products of telomerase reconstituted with 
Figure 4. Location of the upstream conserved region $5^{\prime}-($ CU/GUCA-3' defines the $5^{\prime}$ boundary of the template. (A) Schematic diagram illustrating the potential alignment of the telomeric primer d/GT$\mathrm{TGGG}_{3}$ with wild-type (WT), 42G, $\Delta 42$, $\Delta 43,43 \mathrm{U}$, and $42+\mathrm{U}$ telomerase RNAs. Residues $35-51$ are shown, including the conserved region 5'-(CU)GUCA-3' (boxed). The potential 2-residue spacer region between the $5^{\prime}$ end of the template and the conserved sequence is underlined. Deletions are indicated by spaces in the RNA sequence. Boxed residues indicate ddTTP or ddATP incorporation. The features in the diagram are similar to those in Fig. 1. $(B)$ Telomerase reconstituted with wildtype telomerase RNA (lanes 1-8), 42G RNA (lanes 9-12), $\Delta 42$ RNA (lanes 13,14), $\triangle 43$ RNA (lanes 15-18), 43U RNA (lanes 19-22), or 42 + U RNA (lanes 23-26). Elongation reactions were performed using primer d(GTTGGG $]_{3}$ with $\left[\alpha^{-32}\right.$ P $]$ dGTP and the combination of nucleotides as shown in the figure. The numbers refer to the number of nucleotides added onto the input primer. The gel was exposed to film for 6 days except for lanes 1-4 (1 day) and lanes 5-12 (5 days). Note that lanes 5-12 were from a different experiment than lanes $1-4$ and $13-26$, thus the longer products do not align with those in other lanes.
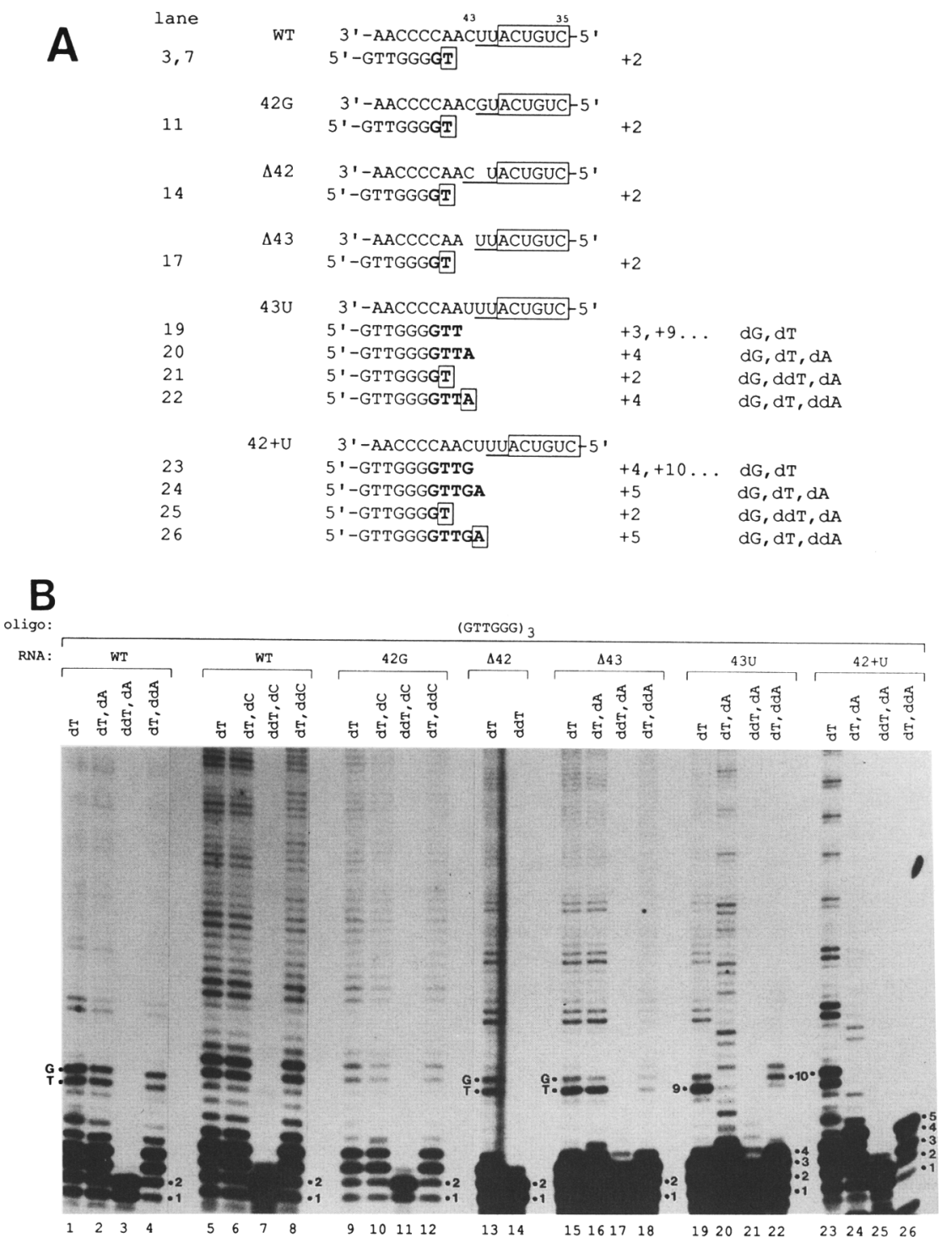

42G RNA, in which the $U$ at position 42 was changed to a $G$, were similar in the presence or absence of dCTP or ddCTP (Fig. 4B, lanes 9, 10, 12), like wild type (lanes 5, $6,8)$. With the primer d(GTTGGG $)_{3},\left[\alpha^{-{ }^{32}} \mathrm{P}\right] \mathrm{dGTP}, \mathrm{dTTP}$, and ddCTP the 42G mutant did not incorporate ddCTP, further indicating that position 42 is not a template residue (lane 12). Chain termination occurred at position $(+2)$ in the presence of ddTTP, like wild type (lane 11).

To test further the role of position 42 , residue 42 was deleted $(\Delta 42)$. Telomerase reconstituted with this mutant RNA generated long products in the presence of $\mathrm{d}(\mathrm{GTTGGG})_{3,}\left[\alpha^{-32} \mathrm{P}\right] \mathrm{dGTP}$ and dTTP. There was a more predominant pause at position $44 \mathrm{~A}$, indicating translocation now occurs after the addition of the second $T$ residue rather than at the first $G$ residue in the repeat (lane 13). Chain termination occurred at +2 from the $3^{\prime}$ end of the primer in the presence of ddTTP (lane 14). In elongation assays with d(GGGTTG) $3, \Delta 42$ did not generate a primer size- labeled product, suggesting that the
$C$ residue, now at position 42 , is no longer the $5^{\prime}$ end of the template (data not shown). This is consistent with the maintenance of 2 residues between the conserved domain and the template $5^{\prime}$ end or with the maintenance of a specific number of residues between the template $5^{\prime}$ end and some other element $5^{\prime}$ of the template, for instance, stem I or stem II (see Discussion).

Elongation of the primer d(GTTGGG) ${ }_{3}$ by telomerase reconstituted with $\Delta 43$ RNA was similar to the elongation of $\mathrm{d}(\mathrm{GTTGGG})_{3}$ by $\Delta 42$, with a predominant pause at position 44A (Fig. 4, lanes 15-18). No incorporation of dATP or ddATP occurred and ddTTP incorporation occurred at the same position from the $3^{\prime}$ end of the primer as wild type $(+2$; lanes $15-18)$. The 6 nucleotide periodicity of the elongation products, with dTTP, suggests that d(GGGGTT) repeats are synthesized and that residue 49 is now used as a template residue in this mutant. Incorporation of dATP or ddATP into elongation products generated by telomerase reconstituted by $43 \mathrm{U}$ RNA 
did occur, as described previously (lanes 20 and 22; Autexier and Greider 1994). In contrast to our previous observation (Autexier and Greider 1994) with this more active preparation of telomerase, some short products were generated by $43 \mathrm{U}$ in the absence of dATP. This suggests that under these conditions, translocation can occur at position 44, bypassing the $U$ at position 43 and that d(GGGGTT) repeats are synthesized instead of d(GGGTTA) repeats (cf. lane 19 with lane 20). Synthesis of d(GGGGTT) repeats by 43U, with dTTP, suggests that residue 49 is a template residue under these conditions. ddATP terminated predominantly at position +4 from the end of the primer; however, premature translocation could bypass this site and generate products seen at position +10 (lane 22). In the presence of ddTTP, chain termination occurred at position +2 , like wild type (lane 21). Results with $43 \mathrm{U}$ are consistent with position 43 being at the $5^{\prime}$ end of the template (Autexier and Greider 1994).

Similar to $43 \mathrm{U}$, elongation products were generated by $42+$ U RNA in the absence of dATP (lane 23). Unlike $43 \mathrm{U}$, however, elongation products were longer in the absence of dATP than in the presence of dATP. With dATP, a predominant labeled product was observed at position +5 , most likely template-directed by the extra U residue (lane 24). ddATP incorporation also occurred at position +5 , indicating that the extra $U$ residue is now part of the template region (lane 26). ddTTP incorporation occurred 2 residues from the $3^{\prime}$ end of d(GT$\mathrm{TGGG}_{3}$ as for wild type (lane 25). This suggests that increasing the number of $U$ residues between the template and sequences $5^{\prime}$ of the template (possibly the conserved region) results in incorporation of the extra $U$ residue into the template.

To characterize further the role of the conserved region, we mutated the sequence of this region. Not to disrupt a potential stem-loop structure involving $5^{\prime}$ (C)UG-3' (Romero and Blackburn 1991), we changed the $5^{\prime}$-(C)UGUCA- $3^{\prime}$ sequence only at the $3^{\prime}$ end, to $5^{\prime}$ (C)UGAGU-3' (38-40AGU). To analyze the products generated by the 38-40AGU mutant, telomerase reconstituted with this RNA was assayed using d(GGGGTT) 3 or d(GGGTTG $)_{3}$ and $\left[\alpha^{-{ }^{32}} \mathrm{P}\right] \mathrm{dGTP}$ and various combinations of dTTP, ddTTP, dATP, and ddATP (Fig. 5). This mutant generated fewer long products than wild type when assayed with either primer in the presence of $\left[\alpha{ }^{-32} \mathrm{P}\right] \mathrm{dGTP}$ and dTTP (lanes $\left.1,2,7\right)$. Incorporation of ddTTP occurred at the same positions as wild type from the $3^{\prime}$ end of $d(\text { GGGGTT })_{3}(+5)$ and d $(\text { GGGTTG })_{3}(+4)$ (lanes 4 and 8). Like for wild type, a primer size-labeled product was generated with d(GGGTTG) ${ }_{3}$ (lanes 7, 8), indicating cleavage still occurs in this mutant. In reactions with $\left[\alpha^{-32}\right.$ P]dGTP, dTTP (or ddTTP), and dATP, elongation products stopped at position +3 from the $3^{\prime}$ end of the primer d(GGGGTT) 3 , suggesting that the $2 U$ residues at positions 41 and 42 are used as template residues (lanes 3,5$)$. In reactions with $\left[\alpha-{ }^{32}\right.$ P]dGTP, dTTP, and ddATP, chain termination occurred at position +2 from the $3^{\prime}$ end of the primer d(GGGGTT) 3 , suggesting that dATP addition is template-directed by the $U$ at po-
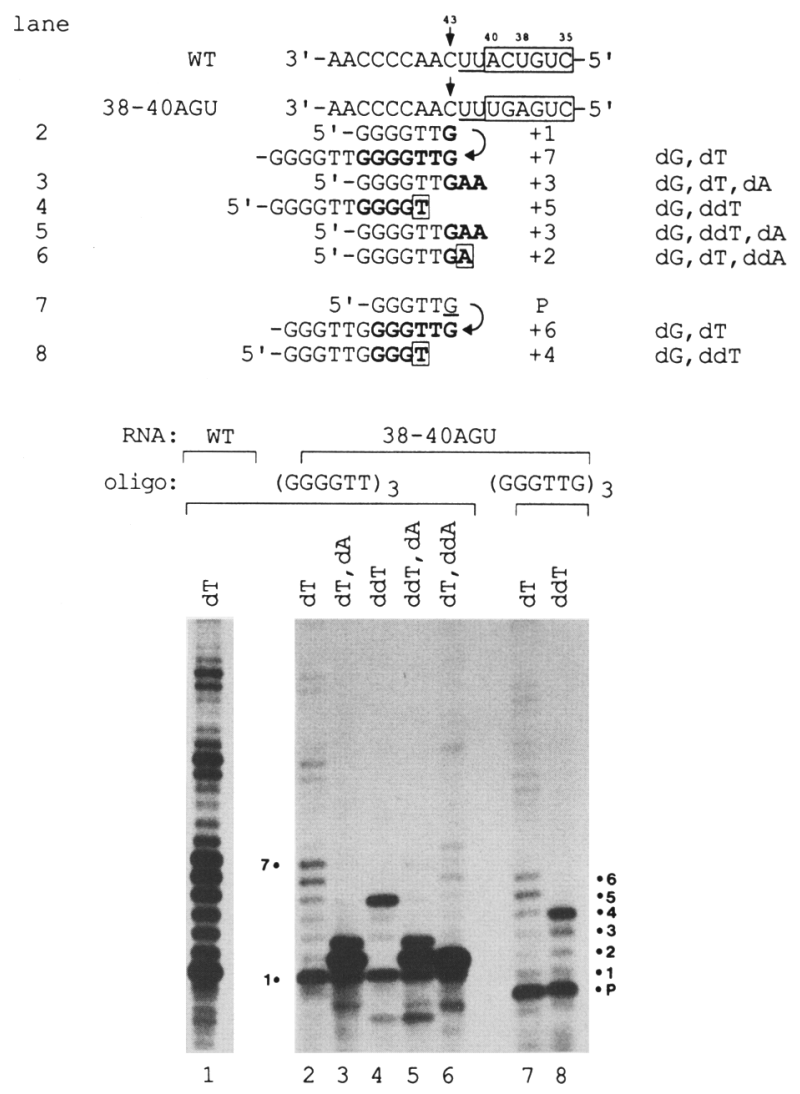

Figure 5. The sequence of the upstream conserved region $5^{\prime}-$ (CU)GUCA-3' defines the $5^{\prime}$ boundary of the template. (Top) Schematic diagram illustrating the potential alignment of the telomeric primer d(GGGTTG) ${ }_{3}$ with wild-type (WT) and 3840AGU telomerase RNAs. Residues $35-51$ are shown, including the conserved region $5^{\prime}$-(CU)GUCA-3' (boxed). The 2-residue spacer region between the $5^{\prime}$ end of the template and the conserved sequence is underlined. The features of this diagram are similar to those in Figs. 1 and 4. (Bottom) Telomerase was reconstituted with wild-type (lane 1) or 38-40AGU (lanes 2-8) telomerase RNA. Elongation reactions were performed using

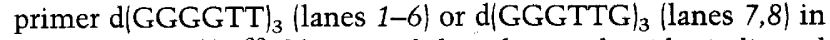
the presence of $\left[\alpha^{-32} \mathrm{P}\right] \mathrm{dGTP}$ and the other nucleotides indicated in the figure. The numbers refer to the number of nucleotides added onto the input primer $(\mathrm{P})$. The gel was exposed to film for 10 days.

sition 42 (lane 6). These data indicated that altering the sequence of the conserved region allows copying past the 5 ' boundary of the template.

To examine further whether the $U$ residues between the original template $5^{\prime}$ end and the conserved domain in the $42+\mathrm{U}$ and 38-40AGU RNA are template residues, telomerase reconstituted with $42+\mathrm{U}$ or $38-40 A G U$ was assayed using the primer d(GGGTTG $)_{3}$ and $\left[\alpha{ }^{-32} \mathrm{P}\right] \mathrm{dATP}$, dTTP, and dGTP (Fig. 6). Telomerase reconstituted with wild-type, $\Delta 42, \Delta 43$, or $43 \mathrm{U}$ was also assayed under the same conditions. Incorporation of $\left[\alpha-{ }^{32} \mathrm{P}\right] \mathrm{dATP}$ into elongation products generated by telomerase reconstituted with $43 \mathrm{U}$ was detected as described previously (Fig. 6, lane 5; Autexier and Greider 1994). The addition of 

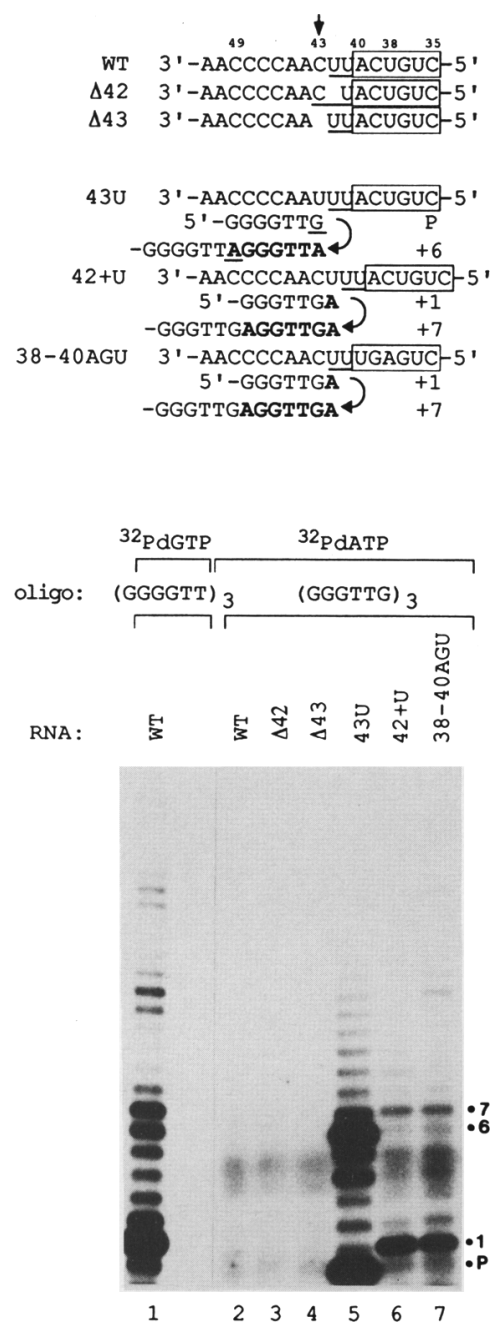

Figure 6. Incorporation of $\left[\alpha^{-32} \mathrm{P}\right] \mathrm{dATP}$ by telomerase reconstituted with mutant telomerase RNAs. $|T o p\rangle$ Schematic diagram of predicted alignments between $43 \mathrm{U}, 42+\mathrm{U}$, and 38-40AGU telomerase RNA and the telomeric primer d(GGGTTG) 3 . The sequence of wild-type (WT), $\Delta 42$, and $\triangle 43 R N A$ from residues $35-51$ are also shown, including the conserved region $5^{\prime}$ (CU)GUCA-3' (boxed). The potential 2-residue spacer region between the $5^{\prime}$ end of the template and the conserved sequence is underlined. Nucleotides in bold represent nucleotides added. (Bottom) The primer d(GGGGTT) ${ }_{3}$ and $\left[\alpha-{ }^{32} \mathrm{P}\right] \mathrm{dGTP}$ were used in telomerase reactions in lane 1 . Telomerase was reconstituted with wild-type telomerase RNA (lanes 1, 2), $\Delta 42$ RNA (lane 3), $\triangle 43$ RNA (lane 4), 43U RNA (lane 5), 42 + U RNA (lane 6), and

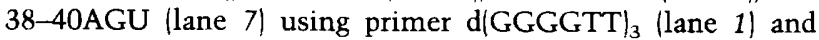
$\mathrm{d}(\text { GGGTTG) })_{3}$ (lanes 2-7) in elongation reactions. The numbers refer to the number of nucleotides added onto the input primers (P). The gel was exposed to film for 4 days.

$\left[\alpha^{-32} \mathrm{P}\right] \mathrm{dATP}$ occurred at the predicted positions, primer size $(\mathrm{P})$ and $+6 \cdot\left[\alpha^{-32} \mathrm{P}\right]$ dATP was also incorporated into elongation products of telomerase reconstituted with $42+U$ and 38-40AGU (lanes 6,7 ). The addition was probably template-directed by the extra $\mathrm{U}(42+\mathrm{U})$ or the $\mathrm{U}$ at position $42(38-40 \mathrm{AGU})$ as suggested by the posi- tion of the radiolabeled product at position +1 . No specific incorporation of $\left[\alpha^{-32} \mathrm{P}\right] \mathrm{dATP}$ by telomerase reconstituted with wild type, $\Delta 42$, or $\Delta 43$ occurred (lanes 2-4). These data further support the conclusion that altering either the spacing between the template $5^{\prime}$ end and the conserved region, or the sequence of the conserved region, alters the $5^{\prime}$ boundary of the template.

\section{Discussion \\ Alternative template and alignment domains of the Tetrahymena telomerase RNA}

The Tetrahymena telomerase template is complementary to one and a half repeats of the telomere sequence. Part of this region is used to align substrates and part is used as a template to specify nucleotide incorporation (Autexier and Greider 1994). We report here that altering the sequence of the alignment and template domains affected processivity of telomerase without abolishing telomerase activity, suggesting that alternative template/alignment domains $3^{\prime}$ of the wild-type template/ alignment region can be functional. Two sites have been proposed for the recognition of telomeric primers (Harrington and Greider 1991; Collins and Greider 1993; Lee and Blackburn 1993). One site, on the telomerase RNA, binds the most $3^{\prime}$ telomeric repeat of the primer or product DNA. The other site, referred to as the anchor site, may be a protein component that binds residues $5^{\prime}$ of, and adjacent to, the sequences bound to the RNA. One of the recently cloned protein components specifically binds primer oligonucleotides (Collins et al. 1995).

Telomerase was active when reconstituted with RNAs containing template domains of different lengths (Fig. 1). The position of ddTTP incorporation indicated that $\mathrm{d} / \mathrm{G}$ GTT), d(GGGTT), and d(GGGGGTT) repeats could be synthesized by telomerase reconstituted with $2 \mathrm{C}, 3 \mathrm{C}$, and $5 \mathrm{C}$ telomerase RNA, respectively. However, telomerase reconstituted with the $2 \mathrm{C}$ RNA did not generate as long elongation products as telomerase reconstituted with the $3 \mathrm{C}$ or wild-type RNA; this may reflect steric constraints during movement of the catalytic site or RNA, difficulties in aligning primer or product sequences with the mutant RNAs, the synthesis of nonwild-type telomeric repeats (Yu et al. 1990; Autexier and Greider 1994/ or specific sequence preferences of the anchor site. Synthesis of noncanonical telomeric repeats, for instance, could affect the interaction of the elongation products with telomerase proteins and the alignment and template domains of telomerase RNA, resulting in inefficient polymerization and translocation. In vivo, Tetrahymen $a$ cells that synthesize $\mathrm{d}\left(\mathrm{G}_{5} \mathrm{~T}_{2}\right)$ repeats become arrested in cell division and die (Yu et al. 1990), suggesting that the sequence alteration of telomere repeats may inhibit telomerase protein-DNA interactions involved in telomere function, thereby affecting telomerase efficiency or processivity. In vivo the $5 \mathrm{C}$ mutant has reduced fidelity, generating $T_{2} G_{6-8}$ as well as $T_{2} G_{5}$ repeats (Yu and Blackburn 1991). In vitro, pausing and 
chain termination at different positions also suggests reduced fidelity of the $5 \mathrm{C}$ mutant.

Telomerase was active when reconstituted with RNAs having permuted template and alignment domains, indicating that the sequence of the template and alignment domain is not stringent (Fig. 2). Telomerase reconstituted with the template permutations generated fewer long products than telomerase reconstituted with wildtype RNA. Although all permutations can potentially specify wild-type repeats, the fact that wild-type activity is not regenerated suggests either specific nucleotides are required at specific template positions or sequences outside the alignment domain are used differently in the mutants. Alternatively if the sequence of the RNA contributes to a structure that is required for translocation the permutations may affect the three-dimensional conformation of the active site and inhibit translocation. The lowered efficiency of mutants with different length template/alignment domains suggests that there must be an active mechanism to specify the boundaries of these domains.

Our data indicate that $d\left(G_{3} T_{2}\right)$ repeats were synthesized by temper 3 , suggesting that the alignment of primers occurs at positions $3^{\prime}$ to the previously defined alignment region (Autexier and Greider 1994). The decrease in processivity suggests that the 3 ' flanking region could also be used for alignment of primers to temper4, temper5, and $51+4 \mathrm{C}$ (Figs. 2 and 3). The absence of long products and the inability of telomerase reconstituted with $51+4$ C RNA to cleave d(GGGTTG) $)_{3}$ suggests that alignment of primers with this RNA occurs at the inserted residues. This supports a requirement for a specific number of residues in the template and alignment domains or in the spacing between substrate bound at the anchor site on the protein and at the template site.

Functional template and alignment domains in the recognition and elongation of substrate DNA may be important to telomerase function in vivo. During developmentally controlled chromosome healing in Tetrahymena, telomerase adds telomeric DNA directly de novo onto nontelomeric sequences (Yu and Blackburn 1991). Generally, in vitro, telomerase adds telomeric repeats onto telomeric or G-rich substrates, but usually not onto nontelomeric or non-G-rich DNA (Blackburn et al. 1989; Harrington and Greider 1991; Morin 1991; Collins and Greider 1993; Lee and Blackburn 1993). Perhaps, in vivo, nontelomeric or non-G-rich substrates align with alternative regions of the telomerase RNA, such as the $3^{\prime}$ flanking regions of the RNA template/alignment domain. Synthesis of telomeric repeats could then occur using the template/alignment domain as template. After translocation and alignment of the newly synthesized wild-type telomeric repeats with the conventional alignment and template domains, a second round of telomere repeat addition could occur.

In certain organisms, including Tetrahymena and Ascaris, the telomeric sequences added onto newly created chromosome break sites are precise, with no noncanonical telomere sequences found at the junction between the chromosome and the newly added telomere se- quences (Budarf and Blackburn 1987; Müller et al. 1991; Yu and Blackburn 1991). In these organisms, alternative alignment domains may be used for the initial recognition of nontelomeric sequences; subsequent repositioning may result in the synthesis of only wild-type telomeric repeats. However, in Plasmodium falciparum, where the telomeric repeats consist of $d(T T / T / C) A G G)$ sequences, an irregular pattern of heterogeneous telomere repeats is added initially onto broken chromosome ends (Scherf and Mattei 1992). In other organisms, such as $S$. cerevisiae and Dictyostelium discoideum telomeric repeats consist of a mixture of different sequences $\mathrm{d}\left(\mathrm{TG}_{1-3}\right)$ and $\mathrm{d}\left(\mathrm{AG}_{1-8}\right)$, respectively (Emery and Weiner 1981; Szostak and Blackburn 1982). Flexibility in the recognition of and telomere addition onto nontelomeric substrates may, in such organisms, be inherent to the telomere complementary region of the telomerase RNA. For instance, although yeast telomeres have irregular repeats, the sequences found at healed yeast chromosomes are complementary to the template domain of $S$. cerevisiae telomerase RNA (Kramer and Haber 1993; Singer and Gottschling 1994).

\section{The location and sequence of the conserved region 5'-(CU)GUCA-3' define the 5' boundary of the template}

Our data indicate that the sequence and location of the conserved region $5^{\prime}$ - $(\mathrm{CU}) \mathrm{GUCA}$ is essential in defining the $5^{\prime}$ boundary of the template domain (Figs. 4-6). In wild-type telomerase RNA, there are two residues between the conserved domain and the template domain. Telomerase reconstituted with $42 \mathrm{G}, \Delta 42, \Delta 43$, or $43 \mathrm{U}$ RNA maintains this 2 residue spacing between the conserved sequence or other sequences $5^{\prime}$ of the template and the start of the template, even for $\Delta 42$, when this results in the exclusion from the template domain of a residue normally in the template ( $\mathrm{C}$ at position 43$)$. The use of the U residue $5^{\prime}$ of $3^{\prime}$-AACCCCAAC-5' as a template residue by telomerase reconstituted with $42+U$ RNA indicates that increasing the number of residues by one between the conserved region and the original $5^{\prime}$ end of the template results in the addition of 1 nucleotide to the $5^{\prime}$ end of the template domain (Figs. 4 and 6). However, in the presence of dATP, elongation by $42+\mathrm{U}$, unlike wild type, is nonprocessive, suggesting copying past the normal template region inhibits translocation. Thus, most products either dissociate or remain paused at the extra U position, resulting in the generation of mostly short products. This differs from the $43 \mathrm{U}$ mutant that generates processive A residue-containing products in reactions with dATP. Perhaps a specific structure is required in the RNA for translocation and the correct location of the conserved sequence contributes to that structure. Moving the conserved sequence in the $42+U$ mutant may cause steric constraints generated by copying the sequence $5^{\prime}$ of the template.

Altering the number of residues $5^{\prime}$ of the template alters the relative distance between the template region and all elements $5^{\prime}$ of the template, including the con- 
served domain and stems I and II. The conserved domain is the best candidate as an essential functional element in the determination of the $5^{\prime}$ template boundary. Stem II is not conserved in other Tetrahymena species (McCormick-Graham and Romero 1995). Deletion of $8 \mathrm{nu}$ cleotides at the $5^{\prime}$ end of the RNA abolishes stem I; however, in vitro reconstitution of telomerase activity with this RNA generates a wild-type 6 base repeat that is not terminated in the presence of dATP (data not shown) unlike products generated by the $42+\mathrm{U}$ and 38-40AGU mutants under the same conditions.

Changing the sequence at the $3^{\prime}$ end of the conserved region $5^{\prime}$-(CU)GUCA-3' to $5^{\prime}$-(CU)GAGU-3' resulted in copying past the normal $5^{\prime}$ template boundary (Figs. 5 and 6), further indicating that the conserved sequence functions to define the $5^{\prime}$ boundary of the template. Telomerase activity reconstituted with $38-40$ AGU is nonprocessive suggesting that the change in the conserved sequence or the use of the spacer as a template region inhibits translocation. During the course of this work, Lingner and co-workers (1994) published the telomerase RNA sequences from additional ciliate species, all of which contained the sequence $5^{\prime}-(C)$ UGUCA-3' two bases upstream from the template region. They proposed that this conserved sequence is engaged in a RNA-RNA or RNA-protein structure involved in preventing polymerization beyond the $5^{\prime}$ end of the template, essentially defining the $5^{\prime}$ boundary of the template domain (Lingner et al. 1994). Our data support this hypothesis. The yeast and mammalian telomerase RNAs lack the conserved sequence present in ciliate telomerase RNAs (Singer and Gottschling 1994; Blasco et al. 1995; Feng et al. 1995; McEachern and Blackburn 1995). Budding yeast telomeres, which consist of $\mathrm{TG}_{1-3}$ repeats for $S$. cerevisiae and of 23 and 25 bp repeats for Candida albicans and K. lactis, respectively (Szostak and Blackburn 1982; McEachern and Hicks 1993; McEachern and Blackburn
1994) may have evolved from simpler sequence repeats through mutation of the conserved region. Absence of a $5^{\prime}$ template boundary regulation may have resulted in polymerization beyond the $5^{\prime}$ end of an originally short template domain and copying of adjacent sequences.

The diagram in Figure 7 illustrates the secondary structure of the $T$. thermophila telomerase RNA (Romero and Blackburn 1991; ten Dam et al. 1991; McCormick-Graham and Romero 1995) with all of the functional domains identified to date. These include the template and alignment domains that appear to be flexible with respect to length, sequence, and position within the telomerase RNA. The relaxed specificity of these domains may be important in vivo for the recognition of nontelomeric substrates during chromosome healing. The observation that the location and sequence of the conserved region upstream of the template domain affects the $5^{\prime}$ boundary of the template region in vitro argues for a role of this conserved sequence as an element in template boundary determination in vivo. This is the first evidence for a functional domain within the telomerase RNA, other than the template/alignment domain, important in telomere elongation.

\section{Materials and methods}

\section{Purification of oligonucleotides}

Oligonucleotides were synthesized by Operon Technologies (Alameda, CA). Oligonucleotides were purified as described previously (Autexier and Greider 1994) and concentrations were determined spectrophotometrically assuming $1 \mathrm{OD}_{260}$ unit equals $20 \mu \mathrm{g} / \mathrm{ml}$.

\section{Preparation of Tetrahymena telomerase}

Tetrahymena telomerase was purified using a protocol modified from Collins et al. (1995). Tetrahymena strains CU428 (kindly

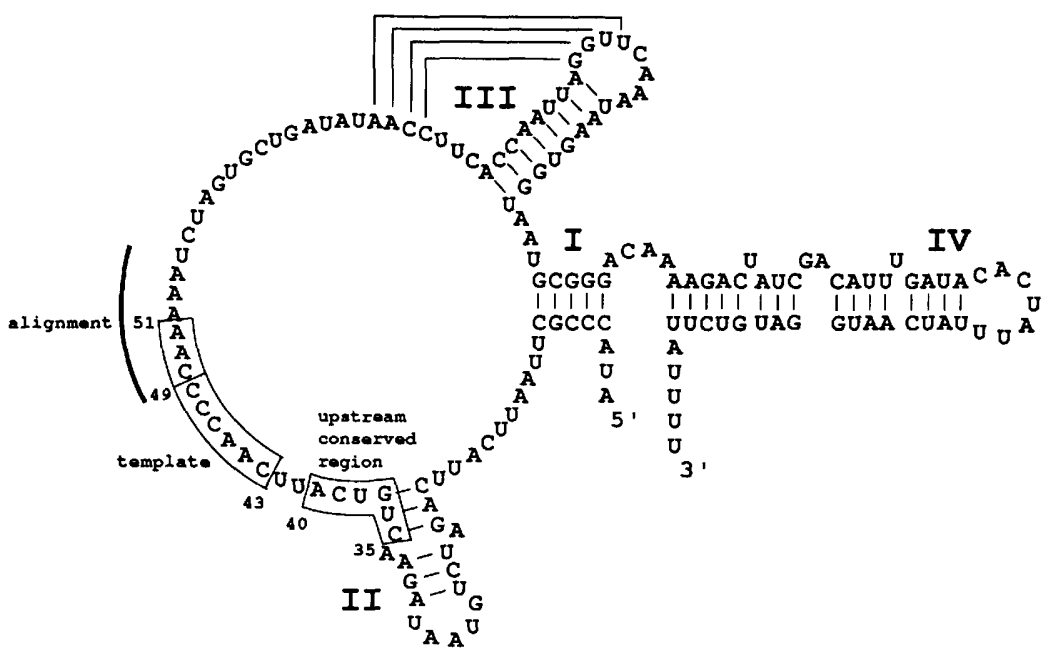

Figure 7. Diagram of the functional domains of the telomerase RNA (secondary structure based on Romero and Blackburn 1991; ten Dam et al. 1991). The telomerase RNA sequence is shown with the upstream conserved region $5^{\prime}$ (CU)GUCA-3' (residues 35-40; boxed) and the template and alignment regions $5^{\prime}$-CAACCCCAA-3' (residues 43-51). The 5'-most 6 residues (boxed) termed the "template" direct synthesis of telomeric repeats. The 3 '-most 3 residues (box) termed the "alignment region" direct the alignment of substrate and product DNA sequences. However, under certain conditions, as discussed in the text, residues $3^{\prime}$ to the alignment region, including the $\mathrm{A}$ residues from positions 52-54 can serve as an alignment domain (underlined) and thus residues $3^{\prime}$ of the template are copied (see text). Data presented provide evidence that the location and sequence of the upstream conserved sequence define the $5^{\prime}$ boundary of the template. It has been suggested previously that this conserved sequence may be involved in RNA-protein or RNA-RNA interactions that prevent DNA polymerization beyond the 5' boundary of the template (Lingner et al. 1994). 
provided by Martin Gorovsky, University of Rochester, NY) were grown, shaken at $30^{\circ} \mathrm{C}$, to a density of $4.0 \times 10^{5}$ cells $/ \mathrm{ml}$ in $2 \times 36$ liters of media ( $2 \%$ proteose peptone, $0.2 \%$ yeast extract, $10 \mu \mathrm{M} \mathrm{FeCl}_{3}$ ) supplemented with $250 \mu \mathrm{g} /$ liter of both ampicillin and streptomycin. After harvesting, the cells were resuspended in Dryls starvation media $(1.7 \mathrm{~mm}$ sodium citrate, $2.4 \mathrm{~mm}$ sodium phosphate, $2 \mathrm{mM} \mathrm{CaCl}$ ) and incubated at $30^{\circ} \mathrm{C}$ for $18 \mathrm{hr}$. Cells were harvested and resuspended in twice the volume of the cell pellet, of T2MG $\left[20 \mathrm{~mm}\right.$ Tris- $\mathrm{HCl}(\mathrm{pH} 8.0), 1 \mathrm{mM} \mathrm{MgCl}_{2}$, $10 \%$ glycerol] with $5 \mathrm{~mm} \beta$-mercaptoethanol ( $\beta-\mathrm{me}), 0.1 \mathrm{~mm}$ PMSF, and protease inhibitors $(0.25 \mu \mathrm{g} / \mathrm{ml}$ each leupeptin and pepstatin; Sigma). Lysis was enhanced by stirring the cells in this buffer at $4^{\circ} \mathrm{C}$ for $20 \mathrm{~min}$ in the presence of $0.2 \% \mathrm{NP}-40$ (Sigma). The lysed cells were centrifuged at 40,000 rpm for $1 \mathrm{hr}$ in a Ti45 rotor (Beckman) at $4^{\circ} \mathrm{C}$, and the supernatant ( $\mathrm{S} 130$ extract) collected and stored at $-70^{\circ} \mathrm{C}$ after quick freezing in liquid nitrogen.

DEAE-purified telomerase was prepared as follows. S130 extract (255 ml; $1900 \mathrm{mg}$ of protein) was loaded onto a $150-\mathrm{ml}$ ceramic hydroxyapatite (AIC) column equilibrated in T2MG with $\beta$-me and protease inhibitors as described above. Proteins were eluted with a $380-\mathrm{ml}$ gradient to $0.2 \mathrm{M} \mathrm{K}_{2} \mathrm{HPO}_{4}$ in T2MG. The ceramic hydroxyapatite column was regenerated and equilibrated in T2MG and the second $\$ 130$ fraction $(225 \mathrm{ml} ; 2700 \mathrm{mg}$ of protein) loaded onto the column. Similarly, proteins were eluted with a $380 \mathrm{ml}$ gradient to $0.2 \mathrm{M} \mathrm{K}_{2} \mathrm{HPO}_{4}$ in T2MG. Fractions containing maximal telomerase activity from the first ceramic hydroxyapatite column $(580 \mathrm{mg})$ were loaded, after diluting three-fold with T2MG onto an 18-ml spermine agarose (Sigma) column equilibrated in T2MG with $0.15 \mathrm{M}$ potassium glutamate $(\mathrm{Kglu})$. Proteins were eluted in T2MG with $0.65 \mathrm{M}$ Kglu. Fractions containing maximal telomerase activity from the second ceramic hydroxyapatite column $(95 \mathrm{mg}$ ) were loaded, after diluting three-fold with T2MG on a 3-ml spermine agarose column as done previously. Proteins were eluted in T2MG with $0.65 \mathrm{M} \mathrm{KGlu}$. Fractions with maximal telomerase activity from both spermine agarose columns were pooled $(60 \mathrm{ml} ; 48 \mathrm{mg}$ ) and loaded onto a 6-ml phenyl Sepharose (Pharmacia) column equilibrated in T2MG with $0.6 \mathrm{M} \mathrm{Kglu}$. Proteins were eluted in T2MG without salt and in T2MG with $1 \%$ Triton X-100. Fractions containing maximal telomerase activity in the no salt elution ( $45 \mathrm{ml} ; 6 \mathrm{mg}$ ) were loaded, after adjusting to no salt, onto a 2-ml DEAE-agarose (Bio-Rad) column equilibrated in T2MG. Protein was eluted in T2MG with $0.4 \mathrm{M} \mathrm{Kglu}$. The peak of telomerase was in fraction $3\left(2 \mathrm{ml}_{;} 4 \mathrm{mg}\right)$. DEAE-purified telomerase ( $2 \mathrm{mg}$ of protein $/ \mathrm{ml}$ of extract) was diluted 10 -fold with T2MG before use in reconstitution reactions. The extract preparations remained active in elongation assays and in reconstitution assays for at least 5 months when stored at $-70^{\circ} \mathrm{C}$. Protein concentrations were determined by a Bradford assay with Bio-Rad dye reagent.

\section{Telomerase elongation activity assay}

Telomerase assays were done as described previously (Greider and Blackburn 1985). Briefly, $20 \mu \mathrm{l}$ of extract was added to $20 \mu \mathrm{l}$ of a $2 \times$ reaction mix. The final concentrations of the components in the assay are $1 \times$ telomerase buffer $[50 \mathrm{~mm}$ Tris $-\mathrm{HCl}$ (pH 8.5), $1 \mathrm{~mm}$ spermidine, $5 \mathrm{~mm} \beta$-me, and $50 \mathrm{~mm} \mathrm{KOAc]}, 800$ nM primer oligonucleotide $(0.2 \mu \mathrm{g}), 100 \mu \mathrm{M}$ dTTP and $0.3125 \mu \mathrm{M}$ $\left[\alpha{ }^{-32} \mathrm{P}\right] \mathrm{dGTP}(1 \mu 1$ of $800 \mathrm{Ci} / \mathrm{mmole}$; New England Nuclear). In assays with telomerase reconstituted with certain mutant RNAs, reaction mixes contained $100 \mu \mathrm{M}$ of both dTTP and dATP or $100 \mathrm{~mm}$ of both dTTP and dCTP. Reactions with 2.5 $\mu \mathrm{M}\left[\alpha{ }^{-32} \mathrm{P}\right] \mathrm{dATP}$ ( $4 \mu \mathrm{l}$ of $400 \mathrm{Ci} / \mathrm{mmole}$; New England Nuclear) contained $100 \mu \mathrm{M}$ dTTP and $50 \mu \mathrm{M}$ dGTP. In reactions with dideoxynucleotides, ddTTP $(100 \mu \mathrm{M})$ replaced dTTP, ddATP $(100 \mu \mathrm{M})$ replaced dATP, or ddCTP $(100 \mu \mathrm{M})$ replaced dCTP. In Figure 1, reactions contained $1 \mathrm{mM}$ ddTTP. Reactions times were $1 \mathrm{hr}$ at $30^{\circ} \mathrm{C}$. Reactions were stopped by adding $100 \mu \mathrm{l}$ of 21 mM EDTA, $10 \mathrm{~mm}$ Tris- $\mathrm{HCl}(\mathrm{pH} 7.5)$, and $1.5 \mathrm{mg} / \mathrm{ml}$ of DNasefree RNase (Boehringer Mannheim). After phenol extraction, 60 $\mu \mathrm{l}$ of $2.5 \mathrm{M} \mathrm{NH}_{4} \mathrm{OAc}, 100 \mu \mathrm{g} / \mathrm{ml}$ Escherichia coli tRNA (Sigma), and ethanol was added to the reactions and precipitated overnight at $-20^{\circ} \mathrm{C}$. Products were centrifuged, pellets dried, and resuspended in formamide containing xylene cyanol. Samples were boiled, cooled on ice, and loaded onto $8 \%$ polyacrylamide, $7 \mathrm{M}$ urea gels and electrophoresed at $1500 \mathrm{~V}$ for $2 \mathrm{hr}$ using $0.6 \times$ TBE buffer. Gels were dried and then exposed to Fuji PhosphorImager screens overnight and then to film (XAR5) for the indicated times.

\section{Micrococcal nuclease treatment and reconstitution assay conditions}

DEAE-purified Tetrahymena telomerase extract was incubated with 0.1 units of micrococcal nuclease (MNase; Pharmacia) per microliter of extract and $1 \mathrm{mM} \mathrm{CaCl}$, for $10 \mathrm{~min}$ at $30^{\circ} \mathrm{C}$. The MNase was inactivated by adding $2.5 \mathrm{~mm}$ EGTA. MNase was prepared as described previously (Autexier and Greider 1994). In standard reconstitution conditions MNase-treated telomerase extract $(\sim 0.2 \mathrm{mg} / \mathrm{ml}$ of protein) containing no detectable telomerase activity was incubated with $5 \mathrm{~mm}$ EDTA and $200 \mathrm{ng}$ of in vitro transcribed telomerase RNA per $20 \mu \mathrm{l}$ of extract for 5 min at $37^{\circ} \mathrm{C}$. One microliter of $200 \mathrm{mM} \mathrm{MgCl}_{2}$ was added before assaying for elongation activity.

\section{Site-directed mutagenesis}

Using methodology similar to that previously described (Autexier and Greider 1994), plasmids containing mutant versions of the Tetrahymena telomerase RNA gene were constructed. Oligonucleotides with sequences corresponding to mutations at the desired positions in the RNA gene were synthesized and used in PCR, with pT7159 digested with EcoRI and HindIII as a template. Briefly, oligonucleotides corresponding to the desired mutation and complementary to the $3^{\prime}\left(3^{\prime}\right.$ T7PCR) regions of the RNA gene were used in PCR with pT7159 cleaved with EcoRI and HindIII as the template. The sequence of the 3' T7PCR oligonucleotide was 5'-CAGTGAATTCGAGCTCGGTACCCGGGG-3', which includes an EcoRI restriction site. The sequences of the mutation specific oligonucleotides were 5'-CATTCAGATCTGTAATAGAACTGTCATTCAACCAAAAATC-3' (Tem2C), 5' -CATTCAGATCTGTAATAGAACTGTCATTCAACCCAAAAATC-3' (Tem3C), 5'-CATTCAGATCTGTAATAGAACTGTCATTCAACCCCCAAAAATC3' (Tem5C), 5'-CATTCAGATCTGTAATAGAACTGTCATTAACCCCAACAAATC-3' (TEMPER1), 5'-CATTCAGATCTGTAATAGAACTGTCATTACCCCAACCAAATC-3' (TEMPER2), 5'-CATTCAGATCTGTAATAGAACTGTCATTCCCCAACCCAAATC-3' (TEMPER3), 5'-CATTCAGATCTGTAATAGAACTGTCATTCCCAACCCCAAATC-3' (TEMPER4), 5'-CATTCAGATCTGTAATAGAACTGTCATTCCAACCCCAAAATC-3' (TEMPER5), 5'-CATTCAGATCTGTAATAGAACTGTCATTAACCCCAAAAATC-3' $\left(5^{\prime} \Delta 43\right)$, 5'-CATTCAGATCTGTAATAGAACTGTCATGCAACCCCAAAAATC-3' $\left(5^{\prime} 42 \mathrm{G}\right)$, 5'-CATTCAGATCTGTAATAGAACTGTCATCAACCCCAAAAATC-3' $(\triangle 42)$, 5'-CATTCAGATCTGTAATAGAACTGTCATTTCAACCCCAAAAATC-3' $(42+$ T), 5'-CATTCAGATCTGTAATAGAACTGAGTTTCAACCCCAAAAATC-3' (38-40AGT), 5'-CATTCAGATCTGTAATAGAACTGTCATTCAACCCCAATTAAATC-3' $(51+2 \mathrm{~T})$, and 5'-CAT- 
TCAGATCTGTAATAGAACTGTCATTCAACCCCAACCCCAAATC-3' $(51+4 C)$. PCR amplification was done in a $100 \mu l$ volume in the presence of $1 \mu \mathrm{M}$ of each primer and $1 \mathrm{ng}$ of EcoRI and HindIII digested pT7159 plasmid DNA using 5 units of Taq polymerase (Perkin-Elmer Cetus) in $1 \times$ PCR buffer [50 mM $\mathrm{KCl}, 10 \mathrm{mM}$ Tris- $\mathrm{HCl}(\mathrm{pH} 8.3), 1.5 \mathrm{mM} \mathrm{MgCl}_{2}$ ) and $250 \mu \mathrm{M}$ dNTPs. Reactions were cycled 30 times for $1 \mathrm{~min}$ at $94^{\circ} \mathrm{C}, 1 \mathrm{~min}$ at $46^{\circ} \mathrm{C}$, and $1 \mathrm{~min}$ at $72^{\circ} \mathrm{C}$.

The PCR amplified DNAs were cleaved with EcoRI and BgIII and cloned into pT7159 cleaved with the same enzymes using conventional cloning techniques (Sambrook et al. 1989). The resulting clones (listed below) contained the mutant versions of the telomerase RNA gene downstream of the T7 promoter, as confirmed by sequencing both strands of the inserted DNA by the dideoxy-mediated chain termination method as per the manufacturer's instructions (U.S. Biochemical). pT743T was made as described previously (Autexier and Greider 1994).

\section{Preparation of RNAs}

RNAs used in reconstitution assays were transcribed in vitro with T7 RNA polymerase (Stratagene) using pT7159, ptem2C, ptem3C, ptem5C, ptemperl, ptemper2, ptemper3, ptemper4, ptemper5, p $443, \mathrm{p} 42 \mathrm{G}, \mathrm{p} \Delta 42, \mathrm{p} 5{ }^{\prime} 43 \mathrm{~T}, \mathrm{p} 42+\mathrm{T}, \mathrm{p} 38-40 A G T$, p51 $+2 \mathrm{~T}$, or p51 $+4 \mathrm{C}$ digested with FokI, as templates. Standard in vitro transcription reaction conditions recommended by the T7 RNA polymerase manufacturer were used. The transcription reactions were treated with RNase-free DNase (Boehringer Mannheim). The RNA concentrations were determined by fluorometer. The in vitro transcribed RNA was 3 nucleotides longer than the endogenous RNA because of the addition of $3 \mathrm{G}$ residues at the $5^{\prime}$ terminus.

\section{Acknowledgments}

We thank Martha Daddario for assistance in growth of Tetrahymena cultures and preparation of S130 extracts, Stephanie K. Smith for excellent technical assistance in the construction of ptem5C, ptemper1, ptemper2, ptemper3, p $\Delta 43$, and $\mathrm{p} 42 \mathrm{G}$, and Ron Pruzan and Stephanie K. Smith for critical review of the manuscipt. C.A. is a fellow of Le Fonds en Recherche et Santé du Québec (Canada). This work was supported by National Institutes of Health grant GM43080 to C.W.G.

The publication costs of this article were defrayed in part by payment of page charges. This article must therefore be hereby marked "advertisement" in accordance with 18 USC section 1734 solely to indicate this fact.

\section{References}

Allsopp, R.C., H. Vaziri, C. Patterson, S. Goldstein, E.V. Younglai, A.B. Futcher, C.W. Greider, and C.B. Harley. 1992. Telomere length predicts the replicative capacity of human fibroblasts. Proc. Natl. Acad. Sci. 89: 10114-10118.

Autexier, C. and C.W. Greider. 1994. Functional reconstitution of wild type and mutant Tetrahymena telomerase. Genes \& Dev. 8: 563-575.

Biessmann, H. and J.M. Mason. 1992. Genetics and molecular biology of telomeres. Adv. Genet. 30: 185-249.

Blackburn, E.H. 1991. Structure and function of telomeres. $\mathrm{Na}$ ture 350: 569-573.

Blackburn, E.H., C.W. Greider, E. Henderson, M. Lee, J. Shampay, and D. Shippen-Lentz. 1989. Recognition and elongation of telomeres by telomerase. Genome 31: 553-560.

Blasco, M.A., W.D. Funk, B. Villeponteau, and C.W. Greider. 1995. Functional characterization and developmental regu- lation of mouse telomerase RNA. Science (in press).

Budarf, M. and E.H. Blackburn. 1987. S1 nuclease sensitivity of a double-stranded telomeric DNA sequence. Nucleic Acids Res. 15: 6273-6292.

Cohn, M. and E.H. Blackburn. 1995. Telomerase in yeast. Science 269: 396-400.

Collins, K. and C.W. Greider. 1993. Tetrahymena telomerase catalyzes nucleolytic cleavage and nonprocessive elongation. Genes \& Dev. 7: 1364-1376.

Collins, K., R. Kobayashi, and C.W. Greider. 1995. Purification of Tetrahymena telomerase and cloning of genes encoding two protein components of the enzyme. Cell 81: 677-686.

Counter, C.M., H.W. Hirte, S. Bacchetti, and C.B. Harley. 1994. Telomerase activity in human ovarian carcinoma. Proc. Natl. Acad. Sci. 91: 2900-2904.

Emery, H.S. and A.M. Weiner. 1981. An irregular satellite sequence is found at the termini of the linear extrachromosomal rDNA in Dictyostelium discoideum. Cell 26: 411419.

Feng, I., W.D. Funk, S.-S. Wang, S.L. Weinrich, A.A. Avilion, C.-P. Chiu, R.A. Adams, E. Chang, J. Yu, S. Le, M.D. West, C.B. Harley, W.H. Andrews, C.W. Greider, and B. Villeponteau. 1995. The RNA component of human telomerase. Science (in press).

Greider, C.W. 1991a. Telomeres. Curr. Opin. Cell Biol. 3: 444 451.

1991b. Telomerase is processive. Mol. Cell. Biol. 11: $4572-4580$.

Greider, C.W. and E.H. Blackburn. 1985. Identification of a specific telomere terminal transferase activity in Tetrahymena extracts. Cell 43: 405-413.

- 1987. The telomere terminal transferase of Tetrahymena is a ribonucleoprotein enzyme with two kinds of primer specificity. Cell 51: 887-898.

. 1989. A telomeric sequence in the RNA of Tetrahymena telomerase required for telomere repeat synthesis. Nature 337: 331-337.

Harley, C.B., A.B. Futcher, and C.W. Greider. 1990. Telomeres shorten during ageing of human fibroblasts. Nature 345: 458-460.

Harrington, L.A. and C.W. Greider. 1991. Telomerase primer specificity and chromosome healing. Nature 353: 451-454.

Hastie, N.D., M. Dempster, M.G. Dunlop, A.M. Thompson, D.K. Green, and R.C. Allshire. 1990. Telomere reduction in human colorectal carcinoma and with ageing. Nature 346: 866-868.

Kim, N.W., M.A. Piatyszek, K.R. Prowse, C.B. Harley, M.D. West, P.L.C. Ho, G.M. Coviello, W.E. Wright, S.L. Weinrich, and I.W. Shay. 1994. Specific association of human telomerase activity with immortal cells and cancer. Science 266: 2011-2015.

Kramer, K.M. and J.E. Haber. 1993. New telomeres in yeast are initiated with a highly selected subset of $\mathrm{TG}_{1-3}$ repeats. Genes \& Dev. 7: 2345-2356.

Lee, M.S. and E.H. Blackburn. 1993. Sequence-specific DNA primer effects on telomerase polymerization activity. Mol. Cell. Biol. 13: 6586-6599.

Lin, J.-J. and V.A. Zakian. 1995. An in vitro assay for Saccharomyces telomerase requires EST1. Cell 81: 1127-1135.

Lingner, J., L.L. Hendrick, and T.R. Cech. 1994. Telomerase RNAs of different ciliates have a common secondary structure and a permuted template. Genes \& Dev. 8: 1984-1998.

Mantell, L.L. and C.W. Greider. 1994. Telomerase activity in germline and embryonic cells of Xenopus. EMBO J. 13: 3211-3217.

Mason, J.M. and H. Biessmann. 1995. The unusual telomeres of 
Drosophila. Trends Genet. 11: 58-62.

McClintock, B. 1941. The stability of broken ends of chromosomes in Zea mays. Genetics 26: 234-282.

McCormick-Graham, M. and D.P. Romero. 1995. Ciliate telomerase RNA structural features. Nucleic Acids Res. 23: 1091-1097.

McEachern, M.J. and E.H. Blackburn. 1994. A conserved sequence motif within the exceptionally diverse telomeric sequences of budding yeasts. Proc. Natl. Acad. Sci. 91: 34533457.

- 1995. Runaway telomere elongation caused by telomerase RNA gene mutations. Nature 367: 403-409.

McEachern, M.J. and J.B. Hicks. 1993. Unusually large telomeric repeats in the yeast Candida albicans. Mol. Cell. Biol. 13: 551-560.

Melek, M., B.T. Davis, and D.E. Shippen. 1994. Oligonucleotides complementary to the Oxytricha nova telomerase RNA delineate the template domain and uncover a novel mode of primer utilization. Mol. Cell. Biol. 14: 7827-7838.

Morin, G.B. 1989. The human telomere terminal transferase enzyme is a ribonucleoprotein that synthesizes TTAGGG repeats. Cell 59: 521-529.

- 1991. Recognition of a chromosome truncation site associated with $\alpha$-thalassaemia by human telomerase. Nature 353: $454-456$

Müller, F., C. Wicky, A. Spicher, and H. Tobler. 1991. New telomere formation after developmentally regulated chromosomal breakage during the process of chromatin diminution in Ascaris lumbricoides. Cell 67: 815-822.

Muller, H.J. 1938. The remaking of chromosomes. Collecting Net 13: 181-198.

Prowse, K.R. and C.W. Greider. 1995. Developmental and tissue specific regulation of mouse telomerase and telomere length. Proc. Natl. Acad. Sci. 92: 4818-4822.

Prowse, K.R., A.A. Avilion, and C.W. Greider. 1993. Identification of a nonprocessive telomerase activity from mouse cells. Proc. Natl. Acad. Sci. 90: 1493-1497.

Romero, D.P. and E.H. Blackburn. 1991. A conserved secondary structure for telomerase RNA. Cell 67: 343-353.

Sambrook, J., E.F. Fritsch, and T. Maniatis. 1989. Molecular cloning: A laboratory manual. Cold Spring Harbor Laboratory, Cold Spring Harbor, New York.

Scherf, A. and D. Mattei. 1992. Cloning and characterization of chromosome breakpoints of Plasmodium falciparum: Breakage and new telomere formation occurs frequently and randomly in subtelomeric genes. Nucleic Acids Res. 20: 1491-1496.

Shippen-Lentz, D. and E.H. Blackburn. 1989. Telomere terminal transferase activity from Euplotes crassus adds large numbers of TTTTGGGG repeats onto telomeric primers. Mol. Cell. Biol. 9: 2761-2764.

-1990. Functional evidence for an RNA template in telomerase. Science 247: 546-552.

Singer, M.S. and D.E. Gottschling. 1994. TLC1: Template RNA component of Saccharomyces cerivisiae telomerase. Science 266: 404-409.

Szostak, J.W. and E.H. Blackburn. 1982. Cloning yeast telomeres on linear plasmid vectors. Cell 29: 245-255.

ten Dam, E., A. van Belkum, and K. Pleij. 1991. A conserved pseudoknot in telomerase RNA. Nucleic Acids Res. 19: 6951 .

Yu, G.-L. and E.H. Blackburn. 1991. Developmentally programmed healing of chromosomes by telomerase in Tetrahymena. Cell 67: 823-832.

Yu, G.-L., J.D. Bradley, L.D. Attardi, and E.H. Blackburn. 1990. In vivo alteration of telomere sequences and senescence caused by mutated Tetrahymena telomerase RNAs. Nature 344: 126-132.

Zahler, A.M. and D.M. Prescott. 1988. Telomere terminal transferase activity in the hypotrichous ciliate Oxytricha nova and a model for replication of the ends of linear DNA molecules. Nucleic Acids Res. 16: 6953-6972.

Zakian, V.A. 1989. Structure and function of telomeres. Annu. Rev. Genet. 23: 579-604. 


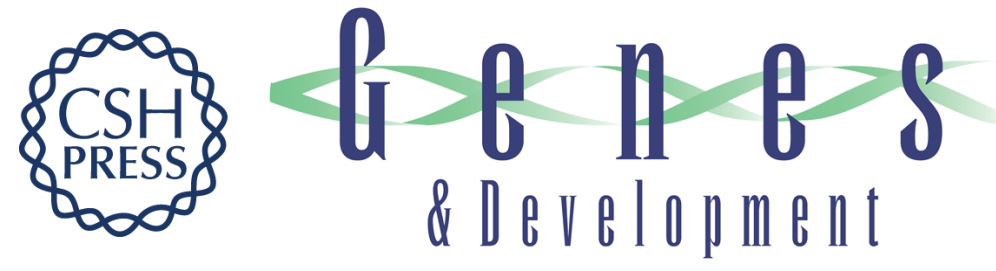

\section{Boundary elements of the Tetrahymena telomerase RNA template and alignment domains.}

C Autexier and C W Greider

Genes Dev. 1995, 9:

Access the most recent version at doi:10.1101/gad.9.18.2227

References This article cites 49 articles, 19 of which can be accessed free at:

http://genesdev.cshlp.org/content/9/18/2227.full.html\#ref-list-1

License

Email Alerting

Service

Receive free email alerts when new articles cite this article - sign up in the box at the top right corner of the article or click here.

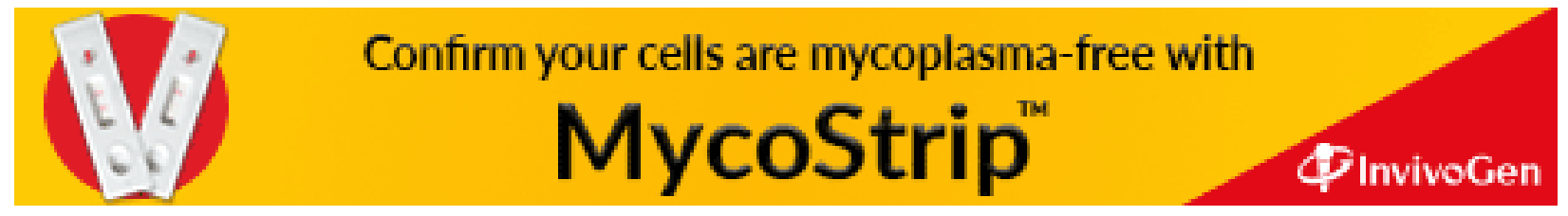

